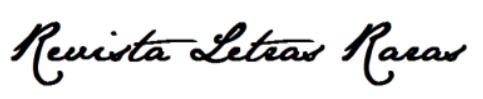

ISSN: 2317-2347 - v. 9, n. 4 (2020)

Todo o conteúdo da RLR está licenciado sob Creative Commons Atribuição 4.0 Internacional

\title{
Teoria da complexidade: sobre o que é isto? ${ }^{1}$
}

\section{Ana Beatriz Miranda Jorge*}

Mestranda do Programa de Pós-Graduação em Linguagem e Ensino (PPGLE) na Universidade Federal de Campina Grande, Paraíba, Brasil.

(iD) https://orcid.org/0000-0002-2286-6978

Williany Miranda da Silva*

Professora Doutora do Programa de Pós-Graduação em Linguagem e Ensino (PPGLE) na Universidade Federal de Campina Grande, Paraíba, Brasil.

(iD) https://orcid.org/0000-0001-6667-2385

Recebido:14 abr. 2020. Aprovado: 03 out. 2020.

\section{Como citar esta tradução:}

JORGE, Ana Beatriz Miranda; SILVA, Williany Miranda da.Teoria da complexidade: sobre o que é isto? Revista Letras Raras. Campina Grande, v. 9, n. 4, p. 318-347, dez. 2020.

No nosso cotidiano, pode ser difícil conviver com a complexidade e a constante mudança. Uma forma de lidarmos é com a busca pelo conforto das rotinas. Outra forma é com a minimização da mudança contínua que experienciamos ao tornar o mundo existente e dinâmico em objetos nomeados e ao pensar nestes como entidades fixas, como rio, árvore, cidade ou pessoa. Transformamos nossas experiências de vidas em histórias, e nossas individualidades mutáveis e contínuas em atributos, atitudes e identidades mais ou menos fixos.

A mesma preferência por um artifício de simplicidade e sincronicidade ocorre no nosso trabalho acadêmico. A mudança é inerente para a maioria de nossos interesses como linguistas

\footnotetext{
1 Este texto foi publicado pela primeira vez em língua inglesa, com o Título "Complexity theory: what's it all about?" do livro Complex Systems and Applied Linguistics (LARSEN-FREEMAN; CAMERON, 2008). Esta tradução é fruto de discussões desenvolvidas no projeto "Configurações de ensino em práticas multidisciplinares de linguagem(ns)" (aprovado pelo Comitê de Ética com o parecer 94344318.6.0000.5182), sob a coordenação do Prof. Dr. Edmilson Luiz Rafael e da Profa. Dra. Williany Miranda da Silva.
}

\anabmjorge@gmail.com

\. williany.miranda@gmail.com 


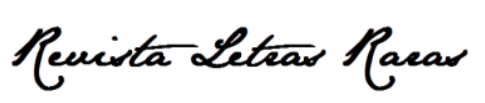

ISSN: 2317-2347 - v. 9, n. 4 (2020)

Todo o conteúdo da RLR está licenciado sob Creative Commons Atribuição 4.0 Internacional

aplicados, e ainda em nossas teorias encontramos, em toda parte, processos convertidos em objetos. Uma resposta pós-moderna para uma ultra simplificação do mundo através de um foco em entidades é fragmentar e dispersar, negar a totalidade, tornando-a múltipla, híbrida e difícil de compreender. A teoria da complexidade, ao contrário, abrange complexidade, interconectividade e dinamismo, e torna a mudança o elemento central para a teoria e o método.

O objetivo da teoria da complexidade é considerar como as partes interativas de um sistema complexo dá origem ao comportamento coletivo do sistema e como tal sistema interage simultaneamente com seu entorno. A área de sistemas complexos intercala disciplinas tradicionais de ciências físicas, biológicas e sociais, assim como engenharia, administração, economia, medicina, educação, literatura e outras. Seu poder vem não só da sua aplicação com diversas disciplinas, mas também do fato de que pode ser aplicado a vários diferentes níveis. Pode, por exemplo, ser aplicado a neurônios no cérebro humano, a células e micróbios no corpo humano, e a flora e fauna em um ecossistema, assim como outras atividades sociais, como a maneira que a informação flui sobre uma rede social ou computadorizada, a dinâmica da transmissão de uma doença infecciosa, e o comportamento de consumidores em uma economia. Cada um desses fenômenos funciona como um "sistema complexo".

É importante notar que o princípio da palavra "complexo" possui um significado especial ao ser usado aqui. Não significa apenas complicado. Embora os agentes ou componentes em um sistema complexo sejam geralmente numerosos, diversos e dinâmicos, uma característica definidora do sistema complexo é que seu comportamento emerge da interação de seus componentes $^{2}$. O comportamento emergente é frequentemente não-linear, significando uma desproporção para seus fatores causais. Em outras palavras, uma grande quantidade de energia, às vezes, pode ser consumido com nada para mostrar. Em outras ocasiões, o mínimo de pressão no sistema pode causar efeitos dramáticos, como as consequências graves para nosso sistema ecológico, mesmo com o menor aumento de temperatura. Os agentes ou elementos em um sistema complexo mudam e se adaptam em resposta a reações. Eles interagem de formas estruturadas, sendo a interação, algumas vezes, direcionada para autoorganização e o surgimento de um novo comportamento. Eles operam em um mundo dinâmico que está raramente em equilíbrio e, ocasionalmente, em caos.

Sistemas complexos têm sido referidos por um número de nomes dependendo de qual dimensão de seus comportamentos está sendo enfatizada. Destacar o fato de que eles mudam

\footnotetext{
2 Note que isto é diferente de dizer que o todo é maior do que a soma se suas partes.
} 


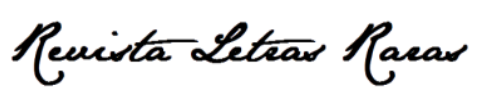

ISSN: 2317-2347 - v. 9, n. 4 (2020)

Todo o conteúdo da RLR está licenciado sob Creative Commons Atribuição 4.0 Internacional

ao longo do tempo, faze-os ser conhecidos como "sistemas dinâmicos", e destacar o fato de que adaptação e aprendizagem ocorrem nesses sistemas, faze-os ser conhecidos, às vezes, como "sistemas adaptativos complexos". Os sistemas complexos nos quais estamos interessadas não possuem delimitações fixas distintivas, eles não são uma "unidade" por si sós. Eles existem apenas através do movimento que os alimenta, à medida que eles desaparecem ou se tornam moribundos pela falta de tais movimentos. Por exemplo, um ciclone tropical se forma devido às condições das correntes marítimas e do ar, e é sustentado por elas. Quando elas mudam, como quando um ciclone tropical atinge o solo, ele enfraquece e, eventualmente, se desfaz. Obviamente que o sistema climático geral permanece, e caso as condições que provocaram 0 primeiro ciclone prevaleçam, um novo ciclone pode, então, ser criado posteriormente na costa. Entretanto, a perturbação particular ocasionada pelo ciclone original desaparece na ausência dos movimentos que 0 alimentaram.

\section{Alguns antecedentes da teoria da complexidade}

A teoria da complexidade possui muitos progenitores disciplinares, o que nos leva, portanto, a sermos seletivas em traçar sua genealogia aqui ${ }^{3}$. Nesta seção, apontamos para influências-chave particulares no desenvolvimento da teoria da complexidade; os próximos dois capítulos são elaborados nelas. Comecemos nosso tratamento em 1940 com o trabalho do biólogo Conrad Waddington. Waddington desafiou a hipótese da vez, que afirmava que a genética carregava a descrição completa do formato de um organismo. Em vez disso, ele mostrou que a genética é apenas o ponto de partida para a embriogênese. Uma vez iniciada a embriogênese, cada etapa do processo de desenvolvimento gera as condições para o próximo. Em outras palavras, "o formato do corpo é literalmente construído pelo próprio processo de construção - e não é especificado em algum conjunto ou modelo totalmente construído e préexistente..." (VAN GEERT, 2003, p. 648-649).

O biólogo von Bertalanffy (1950) seguiu em propor "teoria dos sistemas gerais" para considerar como a ordem complexa surge 4 . Von Bertalanffy opôs-se ao reducionismo em explicar uma entidade como a soma das propriedades de suas partes, defendendo, ao invés

\footnotetext{
${ }^{3}$ Nos baseamos em van Gelder e Port (1995) e van Geert (2003) para um pouco dessa discussão.

${ }^{4}$ Dentre outros que trabalharam com esta teoria foram os antropólogos Margaret Mead e Gregory Bateson e 0 economista Kenneth Boulding.
} 


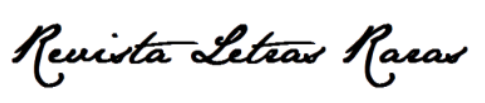

ISSN: 2317-2347 - v. 9, n. 4 (2020)

Todo o conteúdo da RLR está licenciado sob Creative Commons Atribuição 4.0 Internacional

disso, uma abordagem-entendimento das relações entre as partes de sistemas que as conectam a um todo.

Na década de 1970, o químico llya Prigogine (PRIGOGINE; STENGERS, 1984) contribuiria para essa linha de pensamento através do estudo de sistema que ele chamou de "dissipativo". Um sistema dissipativo é expandido para a energia externa deste, a qual uma vez dentro, leva a reações que padrões complexos se auto-organizam. A auto-organização é a criação de outras ordens complexas simultaneamente. O resultado de uma estrutura mais complexa não é planejado ou administrado por uma fonte externa. Portanto, o estudo de sistemas dissipativos foca na interação próxima entre a estrutura, de um lado, e a mudança (ou dissipação), do outro.

Ainda na década de 1970, os biólogos chilenos Humberto Maturana e Francisco Varela (1972) surgiram com uma conscientização importante de seus estudos de visão, os quais contribuíram para a evolução da teoria da complexidade. Eles perceberam que a visão não era percebida pelo sistema nervoso como as lentes de uma câmera percebem uma imagem, mas que é pela luz e a cor que nossos olhos constroem imagens. Baseado nessa descoberta, eles propuseram que organismos vivos são caracterizados pelo que eles denominaram de "autopoiesis". Sistemas autopoiéticos se modificam continuamente e constroem novas estruturas enquanto mantêm suas identidades.

Os desenvolvimentos na década de 1980 modificaram para a busca de compreender a ordem e a estrutura crescentes em sistemas abertos. Haken (1983) e Kelso (1995) trabalharam na relação entre componentes de um sistema que gera uma nova ordem macroscópica que não está presente em quaisquer componentes, um estudo interdisciplinar chamado "sinergética". Em 1984, o Instituto Santa Fé foi fundado e se tornou um centro de pesquisa independente e importante para um entendimento multidisciplinar de sistemas adaptativos complexos. Muitos pesquisadores se envolveram nessa aposta, e podemos citar algumas das maiores figuras ${ }^{5}$. Nós o fazemos juntamente com os livros que eles escreveram para um público leigo, pois os títulos de tais trabalhos são reveladores: As Origens da Ordem: Auto-organização e Seleção na Evolução (1993) e Em Casa no Universo: A busca pelas Leis de Auto-organização e Complexidade (1995), do biólogo Stuart Kauffman; A Qualhada e o Jaguar: Aventuras no Simples e no Complexo (1994), do físico Murray Gell-Mann; e Ordem Oculta: Como Adaptação

5 Waldrop (1992) fornece uma revisão histórica dos acadêmicos associados com o Instituto Santa Fé no livro Complexidade: A Ciência Emergente na Margem da Ordem e do Caos. 


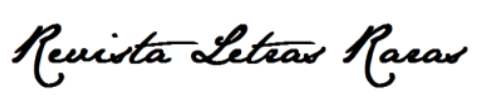

ISSN: 2317-2347 - v. 9, n. 4 (2020)

Todo o conteúdo da RLR está licenciado sob Creative Commons Atribuição 4.0 Internacional

Constrói Complexidade (1995) e Emergência: Do Caos para a Ordem (1998), do psicólogo e cientista da computação John Holland.

Sobrepondo-se a um grande consenso com a teoria da complexidade é a "teoria de sistemas dinâmicos", cuja linhagem é mais matemática do que biológica. Na virada do século, 0 matemático francês Henri Poincaré desenvolveu um estudo de dinâmica não-linear como uma disciplina matemática por si só. Entretanto, foi deslocado quando o computador digital foi desenvolvido depois da Segunda Guerra Mundial. Mesmo os primeiros modelos permitiam o estudo da complexidade e dinamismo desconhecido na história da ciência até aquele determinado período. 0 desenvolvimento do computador também resultou em ideias fundamentais sobre sistemas representados em novas abordagens de sistemas, como a "cibernética" (WIENER, 1948; VON NEUMANN 1958).

Na década de 1960, o matemático francês René Tho, $(1972 ; 1983)$ iniciou um estudo das propriedades de sistemas gerais que exibiam mudanças repentinas, mais especificamente descontinuidades, as quais ele chamou de "catástrofes". A "teoria da catástrofe" envolve a descrição das - repentinas e abruptas - descontinuidades induzidas pelas perturbações locais contínuas de um sistema. As catástrofes, geralmente acionadas por mudanças pequenas, resultam em mudanças repentinas e imprevisíveis de comportamento do sistema inteiro ${ }^{6}$. Nesta mesma época, usando o computador para moldar sistemas de clima, o meteorologista Edward Lorenz também observou as trocas repentina no comportamento que Tom identificou. Lorenz apontou posteriormente para o fato de que sistemas de clima dinâmicos e simulados estabelecem padrões regulares, mas nunca idênticos, denominados "atratores estranhos". Lorenz também identificou que alguns destes padrões são altamente sensitivos a condições iniciais, uma observação que se tornou conhecida como o "efeito borboleta" do título de um trabalho realizado por ele em 1972 para a American Association for the Advancement of Science em Washington D.C. intitulado "Previsibilidade: o bater das asas de uma borboleta no Brasil gera um tornado no Texas?". As asas agitantes da borboleta representam uma mudança pequena na condição inicial do sistema, que afeta uma cadeia de eventos levando a um fenômeno de larga escala como um tornado. Se a borboleta não tivesse batido as asas, o percurso do sistema

\footnotetext{
${ }^{6}$ A importância da teoria da catástrofe para a linguística e a semiótica - uma questão que o próprio Tom expôs vem do fato de que ela se preocupa mais com uma concepção dinâmica das estruturas sistemáticas, uma proposta desenvolvida pela escola de "mofodinâmica". A teoria é essencialmente relacionada com o efeito das variações locais (quantitativo, micro) sobre a estrutura global (qualitativo, macro).
} 


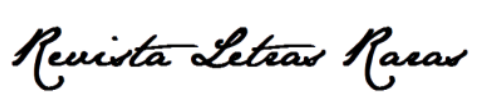

ISSN: 2317-2347 - v. 9, n. 4 (2020)

Todo o conteúdo da RLR está licenciado sob Creative Commons Atribuição 4.0 Internacional

poderia ter sido completamente diferente. Essas observações são mais propensas a serem associadas, nesses dias, à "teoria do caos".

A teoria do caos é o estudo de sistemas dinâmicos não-lineares, isto é, sistemas que não se desdobram ao decorrer do tempo de uma forma previsível e linear. Tal estudo "revelou a natureza caótica de uma vasta variedade de sistemas físicos" incluindo certas classes de redes neurais (VAN GELDER; PORT, 1995, p. 35-36). É importante notar, todavia, que nesse contexto, o caos não é uma desordem completa, mas um comportamento que surge imprevisivelmente em um sistema não-linear. Devido a sua complexidade e devido às trajetórias de sistemas caóticos serem susceptíveis até a perturbações menores, em nenhum ponto da evolução de tais sistemas o caos pode ser previsto.

\section{Aplicando a teoria da complexidade}

Apesar de suas origens diversas, esta pesquisa e estas teorias deixaram suas marcas no que nos referiremos como "teoria da complexidade". A teoria da complexidade lida com o estudo de sistemas adaptativos, às vezes caóticos, emergentes, abertos, auto-organizados, nãolineares, dinâmicos e complexos (LARSEN-FREEMAN, 1997). Nos últimos vinte anos, a teoria da complexidade tem sido considerada a partir de suas áreas originais de biologia, matemática e física, e aplicada em outras disciplinas. O gerenciamento de negócios estava cedo no cenário, adotando ideias e termos da teoria da complexidade para compreender organizações como sistemas complexos (BATTRAM, 1998) e adotando processos dinâmicos para fornecer e exigir correias. Economistas que trabalhavam no Instituto Santa Fé e em outros lugares desenvolveram modelos de sistemas econômicos como sistemas adaptativos complexos, e epidemiologistas moldaram a propagação de doença como um sistema complexo.

Próximo de nossa própria área, psicologistas do desenvolvimento têm visto o potencial em aplicar a teoria dos sistemas dinâmicos ao desenvolvimento motor de crianças e a outros sistemas humanos (THELEN; SMITH, 1994; PORT; VAN GELDER, 1995) e têm sugerido atrair possibilidades para outras áreas da psicologia:

Uma abordagem de sistemas dinâmicos para a cognição e ação promove uma base biológica para as explicações culturais e contextuais da cognição humana... vida mental como emergente das atividades do cotidiano. (THELEN; SMITH, 1994, p. 329). 


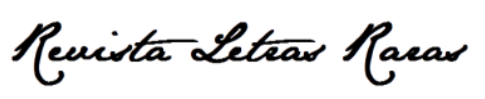

ISSN: 2317-2347 - v. 9, n. 4 (2020)

Todo o conteúdo da RLR está licenciado sob Creative Commons Atribuição 4.0 Internacional

Recentemente, em psicologia, Spivey desenvolveu uma visão dinâmica e complexa da mente que ele chama de "psicologia da continuidade" (SPIVEY, 2007). Ele objetiva convencer psicologistas cognitivos das inadequações da metáfora do computador sobre a mente, e da viabilidade de uma visão de substituição que considera a mente um fluxo contínuo e processos mentais como continuamente dinâmicos. De acordo com Spivey, isso implica abandonar "a hipótese de representações internas, simbólicas e estáveis... continuando com uma descrição dinâmica, ecológica e completa da percepção, cognição e ação" (SPIVEY, 2007, p. 332) que conecta cérebro, corpo e mundo.

Na nossa área de linguística aplicada, Larsen-Freeman (1997) escreveu explicitamente sobre o valor de considerar a aquisição de segunda língua da perspectiva da teoria da complexidade/caos, seguidamente em 2002 (2002a) ao mostrar como tal perspectiva pode ajudar a superar o dualismo que frequentemente envolve nossa área. Meara (1997; 2004; 2006) utilizou uma modelagem dinâmica para descrever o desenvolvimento ou perda de vocabulário. Mais recentemente, de Bot, Lowie e Vespoor (2005; 2007) aplicaram a teoria de sistemas dinâmicos à aquisição de segunda língua, e Herdina e Jessner (2002) utilizaram isto para discutir mudanças na proficiência multilíngue em um nível individual e para fornecer uma descrição de multilinguismo mais dinâmica. Lee e Schuman (2003) utilizaram as lentes dos sistemas adaptativos complexos para visualizar a evolução da língua. Cameron (2003a) aplicou a teoria da complexidade à dinâmica da metáfora no discurso, mostrando como a língua e o desenvolvimento conceitual interagem. Mais recentemente, contribuições para uma questão especial do periódico Applied Linguistics (dezembro 2006), coeditado por Ellis e Larsen-Freeman (2006), direcionaram um número de questões de interesse para a linguística aplicada utilizando a teoria da complexidade em uma abordagem emergente.

Aparentemente o curso da complexidade está se polindo em nossos pés como linguística aplicada, sendo oportuno em considerar como as hipóteses e perspectivas da nossa própria área podem ser desafiadas pela complexidade. Nas páginas que seguem, sugerimos que sistemas complexos podem ser encontrados através da linguística aplicada. A língua utilizada por uma comunidade discursiva pode ser descrita como tal sistema, assim como as interações de aprendizes e seu professor em uma sala de aula, e o funcionamento da mente humana. Nosso objetivo é apresentar que reconceitualizar esses e outros fenômenos em termos de complexidade abrange a possibilidade de novas compreensões e ações. 


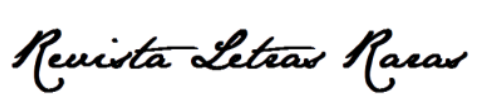

ISSN: 2317-2347 - v. 9, n. 4 (2020)

Todo o conteúdo da RLR está licenciado sob Creative Commons Atribuição 4.0 Internacional

\section{Há sempre algo novo?}

Novamente, é certo pausarmos para prestar homenagem aos nossos antecessores. Certamente, algumas das propostas que apresentamos neste livro não são novas. Por exemplo, o antigo filósofo grego Heráclito enxergava o mundo como algo constituído de um fluxo contínuo, um rio sem fim, uma infinita interpretação de formas e figuras. No Renascentismo, como Widdowson (comunicação própria) nos mostrou, havia uma obsessão com "mutabilité" e como lidar com isso - a crença religiosa era uma forma de impor ordem na mudança perpétua. 0 lluminismo procurou alternativas racionais através da filosofia da ciência, mas nunca havia alguma recusa de variação e mudança, nem alguma pretensão de que as leis subjacentes propostas incluíam qualquer uma em particular.

Entretanto, resolver a tensão entre dois polos de estases e dinamismo tem sido evasivo. Nos tempos mais modernos, a tensão foi criada pelo que Bernstein (1983) chamou de "a ansiedade cartesiana". Varela et al. aperfeiçoa que

\footnotetext{
Este sentimento de ansiedade surge do anseio por uma base absoluta. Quando esse anseio não pode ser satisfeito, a única possibilidade aparenta ser 0 nilismo ou a anarquia. A busca por uma base pode tomar várias formas, mas dada a lógica básica da representatividade, a tendência é buscar tanto por uma base externa no mundo ou por uma base interna na mente. Em tratar a mente e o mundo como polos opostos de objetividade e subjetividade, a ansiedade cartesiana oscila infinitamente entre ambos na busca por uma base. (VARELA et al., 1991, p. 141).
}

A busca por embasamento na mente levou o linguista Chomsky (1965) a investigar a competência mental mais do que a performance, enquanto os sociolinguistas, como Weinreich, Labov e Herzog (1968, p. 99) buscaram encontrar a ordem no mundo social ao criar "um modelo de língua que acomoda os fatos do uso variado... e aponta para uma descrição mais adequada da competência linguística". Linguistas aplicados seguiram o processo, preferindo explicar os fatos da aquisição da língua tanto através de um recurso quanto através de uma competência mental (e.g. GREGG, 1990) ou considerando os fatores de uso da língua, apresentando padrões na variabilidade, o que os levou a adotar e usar o termo híbrido "competência variável" (ELLIS, 1985; TARONE, 1990). Porém a competência mental, quando vista como "irredutivelmente autônoma', não pode semanticamente se relacionar com o mundo 'externo'" (LEATHER; VAN 


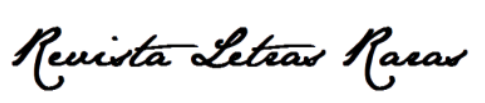

ISSN: 2317-2347 - v. 9, n. 4 (2020)

Todo o conteúdo da RLR está licenciado sob Creative Commons Atribuição 4.0 Internacional

DAM, 2003, p. 6) - o que os linguistas aplicados precisam fazer -, e o hibridismo das demais abordagens socialmente embasadas têm uma tendência de tratar o mundo (contexto) como uma variável independente que influencia a estrutura linguística, não como um sistema dinâmico por si só. Aqui, provavelmente, a teoria da complexidade pode contribuir para uma resolução.

A partir da perspectiva da teoria da complexidade, não há algo estático sobre língua. Não há necessidade em distinguir performance de competência. Os humanos "suavemente reúnem" (THELEN; SMITH, 1994) seus recursos linguísticos a fim de responder de uma forma intencional para as pressões comunicativas em questão. À medida que eles o fazem, padrões emergem, como aqueles padrões de uso da língua que se manifestam no corpora linguístico. Entretanto, o surgimento da estabilidade da performance a partir do uso dinâmico da língua é transformado com um uso posterior (BYBEE, 2006). Desde que os padrões sejam diversificados na estrutura (TOMASELLO, 2000), até mesmo as próprias categorias da língua são negociáveis e sujeitas a mudar. Além disso, o contexto de uso da língua não é mais pré-existente e externo ao usuário da língua do que os recursos linguísticos. Em outras palavras, o contexto não é uma variável de origem estável externo ao individual que afeta a escolha linguística. Ao invés disso, a visão de uma teoria da complexidade enxerga o indivíduo e o contexto como unidos. Por causa desta união, o contexto pode mudar em um processo de co-adaptação entre o indivíduo e 0 entorno.

Essa mudança na perspectiva

reflete a necessidade de compreender sistemas cognitivos, não baseados na relação de suas contribuições e de suas produções, mas na sua conclusão operacional. Um sistema que tem uma conclusão operacional é aquele cujos resultados de seus processos são aqueles processos por si só. (VARELA et al., 1991, p. 139-140).

A vantagem deste tipo de explicação é sua "causalidade recíproca" (THOMPSON; VARELA, 2001), em que há o surgimento "crescente" dos padrões dos indivíduos interagindo, os quais são limitados "decrescentemente" devido a ambas trajetórias históricas do sistema e às normas socioculturais da atualidade. Portanto, uma visão da teoria-informativa da complexidade - compartilhada por Varela et al. e nós mesmas - rejeita o Darwinismo clássico, que, assim como o behaviorismo que ele gerou, enxergava o entorno como externo e independente ao organismo (JUARRERO, 1999, p. 108).

A teoria da complexidade está a um passo à frente. Não só existe uma interação contínua entre o sociocognitivo (nosso termo adotado) e o entorno, como é também o caso de 


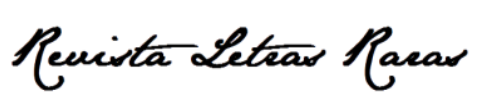

ISSN: 2317-2347 - v. 9, n. 4 (2020)

Todo o conteúdo da RLR está licenciado sob Creative Commons Atribuição 4.0 Internacional

humanos moldarem seu próprio contexto. Da mesma forma, buscar uma explicação para as diferenças individuais nos padrões de causa e efeito, e para as descobertas generalizadas não encaixa em uma perspectiva da teoria da complexidade. Não "é mais suficiente discutir sobre diferenças individuais na aquisição de segunda língua de encontro ao cenário de um aprendiz universal... a variação se torna o fornecimento primário; a categorização se torna uma construção artificial de institucionalização e de investigação científica" (KRAMSCH, 2002, p. 4; LARSEN-FREEMAN, 2006b); como Kramsch afirma, parafraseando Yeats: talvez não seja possível "distinguir o dançarino a partir da dança". Mais recentemente Ushioda (2007) se posiciona da seguinte forma: "As particularidades locais únicas da pessoa como um agente intencional autorreflexivo, inerentemente parte e modelagem do seu contexto, aparenta não ter lugar no tipo de pesquisa anterior.

Apesar de retornarmos a essas ideias ao longo deste livro, por hora apresentamos que a teoria da complexidade nos oferece novos caminhos de conceituar e perceber, substituindo nossos "objetos de interesse" em processos, mudanças e continuidades. Enquanto a pesquisa de complexidade-informativa é recente para linguistas aplicados, ela está progredindo. Não surpreendentemente, muitos dos detalhes discutidos aqui precisam ser desenvolvidos. Mesmo assim, linguistas aplicados deveriam, no mínimo, considerar aquilo que está em oferta e de que maneira isto pode contribuir para o desenvolvimento de nossa área.

\section{Sobre a ação humana e posições críticas}

Alguns linguistas aplicados, ao ouvir falarmos sobre a teoria da complexidade, expressaram suas preocupações sobre seu potencial de negar a ação humana. A natureza autoorganizada dos sistemas complexos pode dar a impressão de que a vontade ou a intenção humana não desempenha o papel de moldar os recursos linguísticos. Uma vez definido o fluxo do sistema, ele se "auto-organiza". Compreendemos essa interpretação e, por sua vez, o protesto. Entretanto, pensamos que a questão pode ser dissipada com uma clarificação. A intencionalidade humana não é ignorada. Certamente aceitamos o fato de que humanos realizam escolhas no momento que utilizam os recursos semióticos, incluindo os linguísticos, que eles têm em mãos para realizar seus objetivos transacionais, interpessoais, auto expressivos, etc. e as dimensões múltiplas de individualidade e identidade, estados afetivos e expressão 


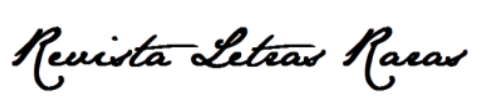

ISSN: 2317-2347 - v. 9, n. 4 (2020)

Todo o conteúdo da RLR está licenciado sob Creative Commons Atribuição 4.0 Internacional

social. Todavia, não é contraditório declarar que, ao mesmo tempo que humanos operam como agentes, os recursos da língua na comunidade individual e de fala são transformados além das intenções conscientes de seus falantes. Não planejamos mudar a língua; a língua muda. 0 linguista histórico Rudy Keller (1985, p. 211) observa que: "Língua é, portanto, uma consequência de ações humanas, embora sejam ações que são apenas intencionalmente transformativas". Retomamos a questão da ação humana no final do Capítulo 3 ao longo deste livro.

Outros levantaram questões sobre a possibilidade de adotar uma posição crítica na teoria da complexidade. Poderia isto lidar com as questões de poder e controle? Poderia isto ser transformativo, no sentido de busca por mudança social? Se a auto-organização e a sensitividade do sistema com condições iniciais sugerem inevitabilidade, então trata-se de um sistema simplesmente destinado a se autorreproduzir? No mundo social, tal produção se assemelharia à situação em que "o rico fica mais rico e o pobre fica mais pobre". Tais questões são pertinentes, uma vez que podemos apenas responder de forma geral no presente momento. Enquanto a teoria da complexidade pode nos apresentar o tipo de intervenção que corrigirá um sistema injustificado, ela pode nos ajudar a compreender melhor o sistema. Como qualquer teoria, a responsabilidade de como ela é utilizada é direcionada pelos seus usuários. Além disso, uma das questões relevantes que surge de uma compreensão da complexidade é a de que nos esforços de corrigir a injustiça em um sistema complexo aberto, pouco, se não quase nada, é impedido. O sistema é sempre aberto para mudança.

Os entendimentos de causalidade lluminista, e até mesmo Marxista, são guiados pelo que Osberg (2007) denomina "uma lógica do determinismo". Esta lógica é baseada em uma concepção linear e individual de causa e efeito, na qual as causas autodeterminadas produzem certas consequências previsíveis; a causalidade é baseada em processos que são completamente determinados. Desta forma, não há liberdade no processo para qualquer outra coisa ocorrer. Entretanto, há uma alternativa para esta lógica disponível na teoria da complexidade. A teoria da complexidade sugere que, em sistemas dinâmicos complexos, 0 sistema tenha a liberdade de desenvolver ao longo de trajetórias alternativas, o que Osberg (2007) chama de "uma lógica de liberdade":

Esta é uma lógica em que a escolha é um condutor no próprio processo parte de sua "mecânica" interna - não algo que ocorre para um processo, algo aplicado a isto a partir do externo. Considerando que processos emergentes não são completamente determinados - eles possuem a 


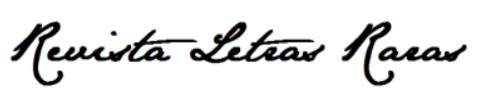

ISSN: 2317-2347 - v. 9, n. 4 (2020)

Todo o conteúdo da RLR está licenciado sob Creative Commons Atribuição 4.0 Internacional

possibilidade de liberdade - a lógica do surgimento poderia ser, pois, caracterizada da mesma forma como uma lógica de liberdade (ao invés de uma lógica de determinação). (OSBERG, 2007, p. 10).

Portanto, para sistemas complexos, enquanto o potencial de um sistema pode ser limitado por sua história, este não é completamente determinado por ela. "Saber como negociar nossa trajetória através de um mundo que não é fixo nem pré-determinado, mas que é continuamente moldado pelos tipos de ação em que nos envolvemos" (VARELA et al., 1991, p. 144) é um desafio para o ser humano.

Ese?

$\mathrm{Na}$ nossa concepção, a mudança mais importante na perspectiva oferecida aos linguistas aplicados pela teoria da complexidade é aquela que o mundo não é composto de "coisas", entidades objetificadas e estáveis. Ao invés disso, a mudança e a adaptação são contínuas no mundo e no fenômeno que as envolvem, e qualquer estabilidade visível surge a partir da dinâmica do sistema. No que segue, apresentamos uma série de perguntas "E se?", as quais partem dessa mudança de perspectiva. E se enxergássemos as questões da linguística aplicada a partir dessa perspectiva? Como compreenderemos ou faremos as coisas diferentemente?

- E se as dicotomias que têm se mostrado óbvias em algumas teorias linguísticas, como aquelas entre a performance e a competência, ocultarem ideias sobre a natureza da linguagem e o seu aprendizado mais do que facilitá-los? O fato é que a linguagem está sendo continuamente transformada pelo uso, denominado "processo estrutural" por Bohm (NICHOL, 2003). Desta forma, o pensamento dualístico é, provavelmente, desnecessário (LARSEN-FREEMAN, 2002a). Enquanto, obviamente, esta não é uma nova descoberta, a teoria da complexidade nos força a argumentar, não ignorar, com 0 dinamismo da linguagem e toda a desordem que ela gera.

- E se a linguística aplicada devesse buscar explicação de como os aprendizes de língua aumentam a participação em uma comunidade de segunda língua mais do que, ou além do que, a maneira que eles adquirem a língua da comunidade (SFARD, 


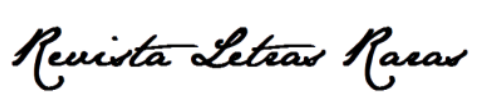

ISSN: 2317-2347 - v. 9, n. 4 (2020)

Todo o conteúdo da RLR está licenciado sob Creative Commons Atribuição 4.0 Internacional

1998)? Desde sua origem recente, muitos pesquisadores em aquisição de segunda língua foram motivados a entrar em um consenso do processo de aquisição da língua que é essencialmente cognitivo e individual. Eles buscam compreender a aquisição de uma gramática cognitiva. Outros têm argumentado que o processo de aquisição da língua é um ato social e não pode ser considerado no nível de cognição individual. $E$ se essas duas posições se unissem em uma compreensão sociocognitiva de desenvolvimento da língua?

- E se o processo de aprendizagem e os agentes envolvidos, isto é, os aprendizes, não pudessem ser utilmente separados (LARSEN-FREEMAN, 1985)? Em algumas áreas de pesquisa em aprendizagem de língua é afirmado que um dia pesquisadores alcançarão um entendimento do processo de aquisição da língua separadamente dos aprendizes. Porém é verdadeiramente possível separar o aprendiz da aprendizagem ou é o caso de que cada indivíduo alcance o sucesso que ele faz de forma única? E se os percursos individuais para a aquisição/participação não precisarem mais ser idealizados (DE BOT; LOWIE; VERSPOOR, 2005)?

- E se a língua fosse vista como um sistema aberto, continuamente evolutivo mais do que um fechado? Conceitos como gramáticas "finalizadas" seriam anômalos, uma vez que sistemas abertos estão constantemente sob mudança, algumas vezes até rápidas. Se não há um estado final para a língua, pode ser inútil pensar em termos de fossilização como um estado final para a aprendizagem de segunda língua (LARSENFREEMAN, 2005).

- E se aprender outra língua fosse uma questão não só de aprender convenções, mas também de inovar, criar tanto quanto, ou mais do que, reproduzir? Resultaria na desconsideração do ensino como algo útil para os alunos desenvolverem o mesmo modelo mental de língua que o professor possuísse, mesmo que fosse algo possível, uma vez que tal visão encorajaria o ensino da conformidade para a uniformidade (LARSEN-FREEMAN, 2003). Além disso, se tudo isso fosse alcançável, estaríamos surpresos se deixássemos os alunos para argumentar sobre "o problema do conhecimento inerente" (WHITEHEAD, 1929), em que eles aprendem as regras e convenções de uma língua, mas não podem usá-las em tempo real para seus próprios propósitos? 


\section{Penista Letras Paras}

ISSN: 2317-2347 - v. 9, n. 4 (2020)

Todo o conteúdo da RLR está licenciado sob Creative Commons Atribuição 4.0 Internacional

- E se verdadeiramente entendêssemos que o ensino não gera aprendizagem? Há, no mínimo, uma relação não-linear entre ambos. Isto resulta, então, na concepção experimental e clássica em que diferenças significantes são atribuídas a "tratamentos" pedagógicos poderiam ser mais generosas ou mais precárias do que deveriam ser quando se trata de atribuir valor para o "tratamento", isto é, os efeitos encontrados poderiam ser devido ao ensino ocorrido antes do experimento; contrariamente, os efeitos do tratamento podem não ser imediatamente visíveis.

- E se as tarefas de aprendizagem de língua não fossem vistas como "quadros" estáticos, e sim, como mais variadas, evoluindo através do uso por indivíduos (COUGHLAN; DUFF, 1994)? Além disso, e se as tarefas fossem vistas, não como insumos fornecidos, os quais então migram de forma fragmentada para a cabeça do aprendiz, mas como possibilidades fornecidas (VAN LIER, 2000) ${ }^{7}$ ? A partir desta última perspectiva, a aprendizagem é construída como "o desenvolvimento de formas cada vez mais efetivas em lidar com o mundo e seus significados" (VAN LIER, 2000, p. 246).

- E se a compreensão através da conversação fosse alcançada, não só por escolher palavras que contivessem significados e então posicionar significados na mesa para algum interlocutor escolher, mas pelo resultado da dinâmica do sistema? E se todos os aspectos do uso da língua fossem dialógicos (BAKHTIN, 1981), incluindo algumas construções da outra pessoa na sua mente a fim de falar de uma forma que suprissem especificamente para ele ou ela, atendendo à resposta dele ou dela e utilizando isto como um retorno adaptativo?

- E se prescrições absolutistas e sobre ensino fossem fadadas a falhar por causa da falta de consideração na natureza orgânica da mudança e o fato de que intervenções pedagógicas são mais valorizadas quando adaptativas, mais do que quando há expectativas em manter a normatização? Se ao invés disso, por exemplo, víssemos aprendizes e professores como uma adaptação contínua para o que outros na sala de aula fazem, então teríamos novas formas de compreender por que certas intervenções do ensino podem falhar e de desenvolver melhores.

\footnotetext{
7 Uma possibilidade é uma oportunidade do uso ou da interação apresentado por alguns objetos ou estados em questão para um agente. Por exemplo, para um ser humano, uma cadeira permite sentar-se, mas para um pica-pau ela pode permitir algo bem diferente (CLARK, 1997, p. 172), assim como um buraco em uma árvore é uma possibilidade para um pica-pau, mas não para um pardal.
} 


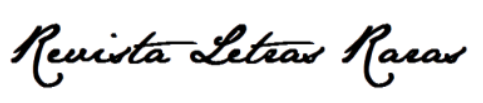

ISSN: 2317-2347 - v. 9, n. 4 (2020)

Todo o conteúdo da RLR está licenciado sob Creative Commons Atribuição 4.0 Internacional

Assim como as descrições de áreas problemáticas da linguística aplicada, os "e se" acima podem não ser novos - o que é novo é a aplicação da teoria da complexidade para interligá-los. Acreditamos que a teoria da complexidade oferece maior coerência em explicar 0 que já conhecemos. Além disso, como já indicamos, ela oferece novos métodos de pesquisa e abre novas áreas de averiguação que não teríamos notado de outra forma, e novos caminhos de intervenção nos problemas na linguística aplicada.

\section{Teoria da complexidade: metáfora ou algo mais?}

Geralmente, quando falamos ou escrevemos sobre usar ideias da teoria da complexidade, somos desafiadas se estamos "só" sendo metafóricas. Há duas formas de responder essa questão: primeiro, rejeitar o "só" e impor a importância da metáfora; segundo, discutir o que significaria afirmar que a comparação entre sistemas na linguística aplicada e sistemas complexos é mais do que metáfora. Nossa opinião, sustentada ao longo deste livro, é de que a teoria da complexidade oferece à linguística aplicada no mínimo uma metáfora nova e importante que traz consigo novas formas de pensar sobre questões na área, e, no máximo, empurra a área em direção a uma mudança teórica radical.

\section{A necessidade da metáfora}

Metáforas são apenas ferramentas literárias para ornamentar a língua; elas são indispensáveis para a mente humana. Sempre que temos que contemplar o abstrato, dar voz à dificuldade, ou dar sentido àquilo que é complicado, nós recorremos à metáfora. A metáfora nos permite "enxergar" ou entender uma coisa considerando outra através de analogias ${ }^{8}$ ou

\footnotetext{
${ }^{8}$ Não há limites claros entre metáfora e analogia, especialmente quando a metáfora é vista como conceitual, assim como a linguística. Muitas metáforas se apoiam na analogia (muito embora algumas metáforas pareçam conectar domínios imageticamente) e algumas analogias são metafóricas, pois elas realizam conexões entre diferentes domínios.
} 


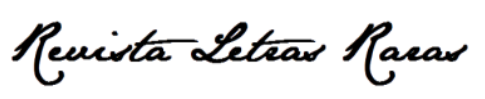

ISSN: 2317-2347 - v. 9, n. 4 (2020)

Todo o conteúdo da RLR está licenciado sob Creative Commons Atribuição 4.0 Internacional

mapeamentos entre dois domínios conceituais ${ }^{9}$ (CAMERON, 1999). Vejamos duas afirmações metafóricas:

1. O cérebro é o centro de controle do corpo.

2. $O$ cérebro é um computador.

O "domínio alvo", isto é, o tópico da metáfora em cada afirmação é o cérebro. $\mathrm{Na}$ afirmação 1 a metáfora de "domínio fonte" é "o centro de controle do corpo", e na afirmação 2 é "um computador". A transformação abordada sobre o mapeamento metafórico da fonte para domínios alvo é muito mais sobre a substituição de um item lexical por outro; ela inclui processos de interação (BLACK, 1979) e/ou combinação (FAUCONNIER; TURNER, 1998) de conceitos, valores e afetos conectados aos itens lexicais. Processos estes que podem produzir novas compreensões e perspectivas não só no domínio alvo, mas na fonte também.

É importante ressaltar que os domínios ligados por um mapeamento metafórico são distintos em alguns sentidos. Quanto mais poética a metáfora, mais ampla é a distância entre os domínios. A afirmação 1, "o cérebro é o centro de controle do corpo", vem de um texto científico de crianças, em que ela foi utilizada para explicar como o cérebro move os membros. Foi utilizado uma figura para ilustrar e encapsular a metáfora, com uma linha transversal na cabeça mostrando um centro de controle como os que podem ser encontrados em um aeroporto ou em uma estação de trem. 0 cérebro estava dividido em blocos denominados "pernas" ou "braços", cheio de engrenagens com alavancas e botões, e manuseado por operários, cuja tarefa era coordenar as ações do resto do corpo. Esta metáfora ajuda a expressar algumas das funções do cérebro, mas é limitada em relação ao seu poder de explicação, pois, de forma essencial, o cérebro não é como um centro de controle concreto com funções separadas.

A afirmação 2, "o cérebro é um computador", carrega algumas semelhanças com a metáfora do centro de controle, mas, na forma de metáfora de "processamento de informação" ou "a mente computadora" ela tem um grande impacto na ciência cognitiva e na linguística nas últimas décadas. As metáforas, ao mapear de um domínio para outro não carregam apenas uma única ideia, mas redes de ideias conectadas. Quando uma ideia metafórica é definida por uma série de metáforas interligadas que são usadas para falar e pesar sobre algum aspecto do

9 O conceito de "domínio" é problemático e tem sido discutido longamente dentro da linguística cognitiva (e.g. CROFT; CRUSE, 2004). Ele é utilizado aqui como uma abreviação conveniente para os conceitos e as ideias anexadas a um item lexical. 


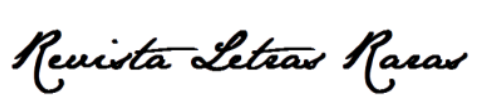

ISSN: 2317-2347 - v. 9, n. 4 (2020)

Todo o conteúdo da RLR está licenciado sob Creative Commons Atribuição 4.0 Internacional

mundo, ela começa a funcionar como um modelo ou teoria. Boyd (1993) denomina essas analogias produtivas de "metáforas teórico-constitutivas". Isto foi o que aconteceu com a teoria do cérebro como um processador de informações. A partir da analogia entre 0 cérebro e 0 computador, os cientistas e linguistas desenvolveram os modelos computacionais do cérebro, os quais utilizaram conceitos da computação para compreender o funcionamento do cérebro e sugeriram linhas de pesquisas e desenvolvimento de teoria posteriores. $O$ que começou como uma metáfora se tornou uma ferramenta útil para investigação e teorização, e fundamentou 0 paradigma cognitivo através de uma gama de disciplinas.

Ao longo do tempo, a natureza metafórica das analogias pode se perder gradualmente, como a consciência das diferenças dos domínios desaparecem e semelhanças se fortalecem. As metáforas podem se tornar tão familiares que nos esquecemos que são metafóricas e começamos a enxerga-las como "a verdade". Isto pode ter acontecido com a metáfora da "mente computacional" na linguística (como sugerido por LANTOLF, 2002, p. 94). Na área de ensino de língua, por exemplo, termos como "insumo" e "produção" simplesmente se tornaram a forma "normal" de se referir a escuta e a fala. Ao minimizar ou desconsiderar as diferenças entre os domínios da analogia, existe um risco de apostar muito alto nas fundamentações metafóricas. Quando a fala se torna uma "produção", por exemplo, podemos perder de vista como os humanos constroem significado por meio da interação social.

Os limites da metáfora do "cérebro como computador" estão sendo cada vez mais amplamente discutidos, atualmente, e novas metáforas e teorias estão sendo introduzidas por socio culturalistas, linguistas cognitivos, e por aqueles, como nós, que encontram inspiração na teoria da complexidade. A declaração mínima que fazemos da teoria da complexidade é que ela acrescenta outra forma de compreender os fenômenos no nosso espaço de problemática na linguística aplicada. Uma declaração bem mais forte seria que a complexidade pode empurrar a área para uma virada paradigmática, uma mudança radical das metáforas teórico-constitutivas (KUHN, 1970). Spivey (2007), por exemplo, realiza esta mesma declaração para a área de psicologia cognitiva. Nossa postura é a de que nos próximos anos podemos ver uma virada paradigmática de teorias inspiradas na complexidade na linguística aplicada, mas há muito o que se fazer para avaliar a sabedoria de tal movimento; este livro objetiva prover alguns dos contextos necessários para realizar tais julgamentos.

$\mathrm{Na}$ história das ideias, a metáfora tem sido frequentemente responsável por provocar trocas de pensamentos através e dentro de disciplinas. A fonte dos domínios das metáforas é 


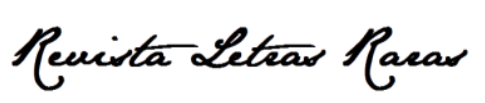

ISSN: 2317-2347 - v. 9, n. 4 (2020)

Todo o conteúdo da RLR está licenciado sob Creative Commons Atribuição 4.0 Internacional

afetada pelo "zeitgeist", e não é coincidência que um afastamento de metáforas sobre máquinas e computadores para metáforas sobre complexidade ou ecologia possa acontecer nesse momento em nossa história, quando o impacto negativo da tecnologia no clima está se tornando cada vez mais marcante, e a globalização, o local e a vida cotidiana estão se tornando muito mais conectadas. A metáfora do computador da mente tomou posse da consciência compartilhada de psicólogos e de outros em um determinado ponto em que os computadores surgiram cheios de promessas e entusiasmo, abrindo novas possibilidades através de sua velocidade e precisão. Talvez não seja surpresa que metáforas de complexidade, dinamicidade e integridade pareçam particularmente sedutoras apenas agora. Maasen e Weingart (2000) examinaram a propagação das metáforas na "dinâmica do saber", e se atentaram para o uso das metáforas a partir da área de "teoria do caos", a qual é, atualmente, vista como uma parte da teoria da complexidade, mas atraiu um grande número de interesse em si por volta do início da década de 1990. Os autores descrevem os estágios em que a metáfora muda da linguagem do dia-a-dia para ciência (por exemplo, "memória", "caos", "complexidade") em que é estabelecido significados técnicos e específicos, então as ideias são metaforicamente transferidas para outras disciplinas (por exemplo, da física para a biologia, ciência cerebral ou teoria da organização); finalmente, as ideias teóricas se tornam o domínio fonte para metáforas antes da linguagem do dia-a-dia, carregando consigo um senso de autoridade científica (por exemplo, "evolução" e "sobrevivência do mais adaptativo" aplicados para a vida social). Com a metáfora ou analogia da complexidade, nos situamos nos estágios intermediários, nas quais ideias estão transacionando através de disciplinas e também começando a penetrar na linguagem do dia-a-dia com seus sentidos mais recentes anexados.

Existem vários perigos associados à metáfora que são relevantes de conhecer. Um primeiro problema pode surgir quando uma ideia como "caos" tem ambos significados científicos e de senso comum. $\mathrm{O}$ uso dos termos pode evocar ressonâncias e significados simultaneamente dos dois contextos, o que pode levar ao pensamento turvo ou às "imposturas intelectuais" (SOKAL; BRICMONT, 1998). Termos técnicos ou matemáticos podem ser utilizados de formas errôneas ou sem sentido, mas soar impressionante e autoritário.

O segundo problema é que há muito foi reconhecido a proporção em conjunto dos domínios fonte e alvo na metáfora, ambos aspectos ocultos e realçados dos domínios (LAKOFF; JOHNSON, 1980). Aspectos do domínio alvo que são fácil e vividamente conectados com o domínio fonte serão realçados; enquanto outros aspectos do domínio alvo podem ser ocultados, 


\section{Penista Letras Paras}

ISSN: 2317-2347 - v. 9, n. 4 (2020)

Todo o conteúdo da RLR está licenciado sob Creative Commons Atribuição 4.0 Internacional

por causa da falta do aspecto correspondente do domínio fonte para ser aplicado. Se compararmos Julieta ao sol (como na metáfora Shakespeariana demasiadamente citada), realçaremos sua beleza e importância, mas ocultaremos outros aspectos que podem ser importantes, como seu contexto familiar. Ellis (2007) direciona este perigo em sua resposta para de Bot et al. (2007) sobre a aplicação da teoria dos sistemas dinâmicos na aquisição de segunda língua. Ele adverte que, ao realçar a variabilidade individual, a analogia dos sistemas dinâmicos minimiza, ou oculta, regularidades bem atestadas no desenvolvimento da língua através de indivíduos. Neste capítulo já abordamos a questão de que uma metáfora do sistema pode contextualizar a ação humana. Assim como qualquer uso da metáfora ou da analogia, precisamos nos alertar para o que está sendo ocultado pela nossa escolha de metáfora, da mesma forma do que está sendo evidenciado, e considerar seriamente a necessidade de explicar os limites do mapeamento - o que não pode ser declarado pela perspectiva dos sistemas complexos.

Um terceiro problema está em assumir que uma simples metáfora, mesmo uma que explora uma extensa rede de conceitos, será o bastante para sustentar a teoria. Devido às diferenças de domínio que se encontram no cerne dos mapeamentos metafóricos, nem uma única metáfora pode sequer servir como um mapeamento completo de uma ideia para outra. Para construir uma teoria ou entendimento mais eficaz precisamos proporcionar metáforas adicionais (SPIRO et al., 1989). A teoria da complexidade pode oferecer uma analogia rica para a linguística aplicada, mas é pouco provável de ser suficiente, e precisará ser complementada com outras teorias e/ou outras metáforas, a fim de considerar a questão de compatibilidade.

O quarto problema potencial em utilizar a metáfora é que, se uma metáfora for empregada efetivamente e validamente, os usuários precisam de um certo nível de conhecimento do domínio fonte. Cameron (2003a) apresentou alguns dos problemas que surgem ao compreender metáforas, quando um ou ambos os domínios envolvidos em uma metáfora não são familiares. Nesses casos, o conhecimento restrito pode levar a troca dos mapeamentos de domínios cruzados de seus significados intencionados. Para prevenir os equívocos de mapeamento e o uso impreciso da metáfora da complexidade, um bom entendimento da base da teoria é vital, e tentaremos apresentá-lo neste livro. Explicaremos os conceitos da teoria da complexidade e examinaremos como eles podem ser mapeados de forma consistente e justificada de e para os domínios da linguística aplicada. 


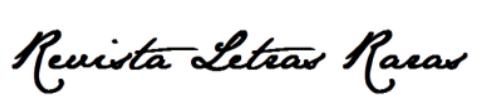

ISSN: 2317-2347 - v. 9, n. 4 (2020)

Todo o conteúdo da RLR está licenciado sob Creative Commons Atribuição 4.0 Internacional

Apesar dos riscos associados com a racionalização através da metáfora e da analogia, essas ferramentas são indispensáveis. Cada tentativa de compreender o mundo em entendimentos prévios de alguma forma e metáfora oferece um método construtivo particularmente imaginativo e de difícil alcance.

\section{Mais do que a metáfora}

A teoria da complexidade vai atender à linguística aplicada mais do que a metáfora se funcionar como uma ponte que nos leva a uma nova forma de pensar ou a uma abordagem teórica, que é desenvolvida dentro da área. A metáfora serve como um "recurso temporário para pensar" (BAAKE, 2003, p. 82) e é eventualmente mencionada, na literatura, como teoria, pesquisa e prática específica de uma área.

Como a ideia de complexidade se espalha para áreas fora de suas origens na matemática e na ciência, e como ela é utilizada de maneira mais abrangente, existe uma ampliação e uma flexibilização dos comprometimentos teóricos, como definir critérios de categorias (MAASEN; WEINGART, 2000; BAAKE, 2003). Por exemplo, os critérios de classificação para sistemas complexos nas áreas originárias são bastante explícitos, enquanto que para aplicações fora dessas áreas originárias, os critérios parecem ser "deliberadamente vagos" (BAAKE, 2003, p. 197). Holland (1995) apresenta uma definição explícita, em que um sistema complexo deve mostrar evidências de sete propriedades e mecanismos básicos, mas também oferecer uma definição mais abrangente e vaga, em que os sistemas adaptativos complexos são sistemas que exibem "coerência de frente para mudança" (1995, p. 4). Dado esse deslize na natureza dos critérios, estes se tornam cada vez mais difíceis de distinguir declarações de classificação de declarações de similaridade metafórica. Se declararmos, por exemplo, que "a interlíngua é um sistema complexo", saberíamos que a interlíngua cumpre os critérios em ser um sistema complexo ou que a interlíngua é metaforicamente como um sistema complexo? Precisamos ser aptos, já que a teoria da complexidade supera seu papel metafórico e transitório em desenvolver uma classificação específica da área. Isto é, precisamos ser aptos a responder àquela questão utilizando os critérios definidos para a área de linguística aplicada. Categorização é apenas um aspecto da construção da teoria ao lado de outros, incluindo: a relação para com outras teorias e trabalhos existentes; a clarificação da natureza das hipóteses, 


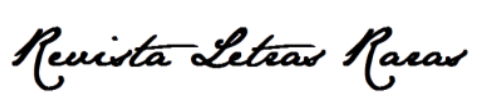

ISSN: 2317-2347 - v. 9, n. 4 (2020)

Todo o conteúdo da RLR está licenciado sob Creative Commons Atribuição 4.0 Internacional

o que conta como dados e evidência, o papel da descrição, explicação e predição, e o desenvolvimento de métodos empíricos. Retornaremos para essas questões no Capítulo 8.

Neste livro, objetivamos apresentar a teoria da complexidade como uma ponte metafórica para leitores e contribuir para o desenvolvimento de uma abordagem teórica da complexidade para a linguística aplicada.

\section{A complexidade em relação às teorias existentes}

Ao ler a seção "E se?", o leitor pode ter pensado sobre uma ou mais teorias que se dirigem às mesmas questões. Como a teoria da complexidade é propícia dentre as ciências sociais devido ao seu "poder multidisciplinar" (WILSON, 2000, p. 4), ela pode não substituir teorias existentes, mas sim, funcionar como um nível abstrato, supradisciplinar, mais do que abordagens teóricas atuais, oferecendo um conjunto geral de padrões, resultados e descrições que podem ser aplicados a vários tipos diferentes de sistemas (BAAKE, 2003). Propomos que a linguística aplicada tem muito a ganhar se se apoiar na complexidade. $O$ que isto pode implicar para a teoria?

Uma teoria ou abordagem teórica é utilizada para descrever e explicar (e, em alguns paradigmas, prever) fenômenos empíricos. A teoria e a teorização são tão essenciais para trabalhos advindos das ciências sociais e humanas como são das ciências naturais. Na verdade, é impossível trabalhar ou viver sem teorizar. A cada minuto do dia estamos categorizando e elaborando hipóteses, prevendo e explicando. A fim de fazer algo simples como entrar no ônibus para o trabalho, utilizamos e construímos teorias sobre o quão "pesado" o tráfico está em diferentes horas do dia, o quão as diversas ruas se conectam, ou os procedimentos esperados para comprar ingressos. Essa construção de teoria informal e intuitiva é parte da nossa capacidade cognitiva como seres humanos. A construção de teoria formal se forma a partir dessa capacidade, elaborando hipóteses explícitas, denominando categorias precisamente e testando explicações para a consistência e congruência lógica com o que é observado no mundo real.

A teoria que escolhemos trabalhar, explicitamente como pesquisadoras e supostamente como professoras, ditará como descrevemos e investigamos o mundo. Ela controla como selecionamos, dentro de tudo que é possível, o que investigar ou explicar, que tipos de questões 


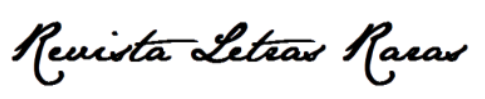

ISSN: 2317-2347 - v. 9, n. 4 (2020)

Todo o conteúdo da RLR está licenciado sob Creative Commons Atribuição 4.0 Internacional

perguntamos, como os dados são coletados e que tipos de explicações dos dados são consideradas válidas.

Ao decidir qual tipo de dados coletar, uma abordagem de teoria da complexidade com seu foco central na dinâmica nos requere olhar para a mudança e para os processos que levam à mudança, mais do que para entidades imutáveis e estáticas. Além disso, os dados não são lapidados antes da análise para se livrar do "barulho" inconveniente (DE BOT; LOWIE; VERSPOOR 2007). Esperamos que os dados sejam barulhentos e bagunçados, porque a dinâmica dos sistemas complexos produz variabilidade. Além disso, uma característica-chave da teoria da complexidade é o contexto ser visto como uma parte intrínseca de um sistema, não como um histórico contra o qual a ação ocorre. Quando os dados são coletados de um sistema complexo, a informação sobre o contexto é, portanto, incluída automaticamente como parte dos dados.

Uma abordagem da complexidade requer novas formas de explicação de fenômenos relacionados com a língua que não confia no reducionismo e afasta explicações simples de causa e efeito para explicações que envolvem processos de auto-organização e surgimento. Por exemplo, abordagens de sistemas complexos de aquisição de língua não requerem conhecimento inato de regras linguísticas, mas explicam o desenvolvimento da língua através da auto-organização na mente de indivíduos envolvidos em interações sociais e através de autoorganização em níveis mais altos do que o individual. Além disso, a teoria da complexidade requer uma revisitação da ideia de prever o comportamento. Enquanto a pesquisa positivista é baseada na hipótese de que há leis universais e elas definem, pois, a previsibilidade como um objetivo do processo de investigação, a perspectiva da teoria da complexidade acredita que duas situações não podem ser semelhantes o suficiente para produzir o mesmo comportamento; portanto, a previsibilidade se torna impossível. Sabemos, todavia, em um nível mais geral, os tipos de comportamento propensos a acontecer nos sistemas complexos e podemos mapeá-los a partir do sistema específico que estamos interessadas para possibilitar e estimar padrões. 


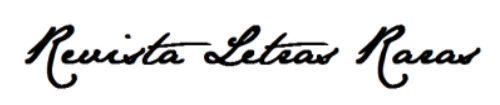

ISSN: 2317-2347 - v. 9, n. 4 (2020)

Todo o conteúdo da RLR está licenciado sob Creative Commons Atribuição 4.0 Internacional

O foco central em uma abordagem da complexidade é o estudo do comportamento de sistemas complexos. Os próximos dois capítulos descrevem em detalhes as característicaschave desses sistemas não-lineares, abertos e dinâmicos. 0 entendimento de sistemas complexos promove a fundamentação de estruturas teóricas para as questões da linguística aplicada, como o uso da língua, o desenvolvimento da primeira e segunda língua, e sala de aula de língua. É necessário que este entendimento seja complementado com outras teorias compatíveis que, juntas, supram tudo que precisa ser descrito e explanado sobre os fenômenos de interesse. Por exemplo, para teorizar sobre a sala de aula de língua, precisamos de uma teoria de aprendizagem instrutiva e de interação social, assim como uma teoria da linguagem. No que segue, discutimos brevemente quais ferramentas e teorias conceituais temos considerado ao construir nossa abordagem da teoria da complexidade.

Tomamos muito das utilizações da teoria dos sistemas dinâmicos para 0 desenvolvimento (SMITH; THELEN, 1993; THELEN; SMITH, 1994; KELSO, 1995; PORT; VAN GELDER, 1995). A teoria dos sistemas dinâmicos dispensa a distinção entre competência e performance (DE BOT; LOWIE; VERSPOOR, 2005). Os pesquisadores do sistema dinâmico não sentem necessidade de invocar uma competência mental subjacente para explicar 0 comportamento humano dentro do contexto. Ao invés disso, a atividade constante de um organismo modifica continuamente seus estados neurais, assim como o crescimento modifica as dimensões físicas do corpo.

As abordagens emergentistas para a linguagem (MACWHINNEY, 1998; 1999) têm sido oferecidas como uma alternativa para gramáticas que especificam conjuntos fixos de regras que descrevem sentenças gramaticais, e, da mesma forma, podem servir como uma abordagem da complexidade ao considerar certos aspectos do desenvolvimento da língua. 0 emergentismo na aquisição da primeira língua (e.g. o Modelo de Competição de MATES; MACWHINNEY, 1989) e na aquisição da segunda língua (ELLIS, 1998; 2005; ELLIS; LARSEN-FREEMAN, 2006; LARSEN-FREEMAN, 2006b; MELLOW, 2006) está intimamente aliado com uma abordagem da teoria da complexidade para o desenvolvimento da língua.

O conexionismo se caracteriza por modelos que utilmente descrevem a dinâmica de alguns aspectos do uso e do desenvolvimento da língua (GASSER, 1990; SPIVEY, 2007). Os conexionistas utilizam computadores para moldar redes neurais no cérebro, e estas redes são sistemas complexos dinâmicos. Enquanto alguns nós na língua modeladora de redes conexionistas são fortalecidos como dados da língua, outros são enfraquecidos. A língua pode, 


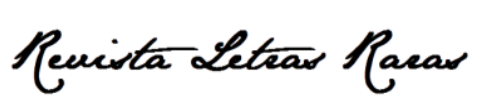

ISSN: 2317-2347 - v. 9, n. 4 (2020)

Todo o conteúdo da RLR está licenciado sob Creative Commons Atribuição 4.0 Internacional

portanto, ser considerada como um "conjunto estatístico" de elementos interativos (COOPER, 1999, p. ix), modificando-se constantemente. Devido à sua natureza dinâmica, modelos conexionistas combinam representações da língua com o desenvolvimento da língua, evitando a necessidade de duas teorias diferentes (MELLOW; STANLEY, 2001). Assim, "O conexionismo proporciona um veículo conceitual do estudo das condições sob qual forma emergente surge e a forma em que o surgimento pode ser limitado" (ELMAN et al., 1996, p. 359). Todavia, o conexionismo lida com o tempo de forma particular que não é sempre compatível com a abordagem da complexidade que estamos desenvolvendo. Além disso, devido ao esquecimento ser "catastrófico" na maior parte da aprendizagem conexionista, em que a aprendizagem de algo tardio substitui o aprendizado de algo precoce, tornando o aprendizado precoce irremediável, os modelos conexionistas de um certo tipo - aqueles que operam com uma base de propagação de algoritmo - não se emprestam para modelos de aquisição de segunda língua (NELSON, 2007). No final, o conexionismo ainda se encontra inserido em uma metáfora computacional do cérebro/mente. É útil, mas há limites para essa utilidade.

Quando se trata de enxergar a linguagem em termos de complexidade, várias teorias linguísticas existentes compartilham com nossa perspectiva de complexidade a hipótese de que formas da língua emergem do uso da língua. Gramática baseada no uso (e.g. BYBEE 2006), gramática emergente (e.g. HOPPER, 1988; 1998), linguística cognitiva (e.g. LANGACKER, 1987; 1991; BARLOW; KEMMER, 2000; CROFT; CRUSE, 2004), e gramática construtiva (GOLDBERG, 1999) consideram a gramática como o resultado da experiência de alguém com o uso da língua. Linguística de corpus (e.g. SINCLAIS, 1991), análise conversacional (e.g. SCHEGLOFF, 2001), e linguística computacional (e.g. JURAFSKY et al., 2001) forneceram à linguística aplicada o acesso para a natureza e a uma gama de experiências que um falante médio tem com a língua, o que aumenta nosso entendimento de língua como um sistema emergente.

A linguística probabilística, diferentemente da linguística tradicional, abraça a variedade do comportamento linguístico e enxerga a regularidade linguística como um fim, não como um meio (PIERREHUMBERT, 2001; BOD; HAY; JANNEDY, 2003). A linguística probabilística trata a manifestação dos fenômenos linguísticos, por exemplo, como julgamentos de uma boa formação que não são absolutos, mas exibem propriedades de um contínuo. A linguística probabilística não só assume que a língua se modifica ao longo do tempo, mas também que esta é inerentemente variável, tornando-a compatível com a abordagem da complexidade. 


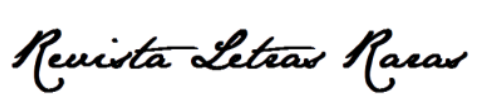

ISSN: 2317-2347 - v. 9, n. 4 (2020)

Todo o conteúdo da RLR está licenciado sob Creative Commons Atribuição 4.0 Internacional

No entanto, assim como a teoria da complexidade, as teorias linguísticas funcionais não abstraem a língua de seu contexto em uma tentativa de obter sua essência, o que difere da teoria da complexidade, pois muitos não interpretam o uso da língua como um processo dinâmico. Provavelmente a linguística sistêmica-funcional de Halliday (1973), a qual enxerga a língua como um processo social que contribui para a realização de diferentes contextos sociais, é a que mais se aproxima. A gramática de Halliday é funcional "no sentido de que é elaborada para considerar o uso da língua" (HALLIDAY, 1994, p. xii), e oferece uma base fundamentada para descrever como e porque a língua varia em relação aos que estão utilizando-a e aos propósitos pelos quais ela é utilizada (HALLIDAY; HASAN, 1989). A importância que a linguística sistêmica-funcional concede aspectos do contexto social de uma forma que influencia o uso dos falantes de recursos linguísticos disponíveis para construir sentido é compatível com as ideias apresentadas neste livro.

A linguística integracionista de Harris apresenta outra teoria que sobrepõe algumas de nossas premissas. A linguística integracionista enxerga os signos linguísticos não como "objetos autônomos de qualquer tipo, seja social ou psicológico", mas como "produtos contextualizados da integração de várias atividades por indivíduos em situações particulares de comunicação" (HARRIS, 1993, p. 311). Este tipo de linguística é situado ou contextualizado, isto é, os papéis da língua em atividades sociais são o cerne da definição da língua (VAN LIER, 2004, p. 20). Ademais, o integracionismo se recusa a aceitar o texto e o contexto, a língua e o mundo são distintos e são categorias estáveis (TOOLAN, 1996).

Quando consideramos a aprendizagem e a interação, a teoria sociocultural de Vygostky (e.g. LANTOLF; PAVLENKO, 1995; LANTOLF, 2006a) pode, de forma útil, ser parte de uma estrutura teórica da complexidade que extingue o limite entre a aprendizagem de língua e o uso da língua (CAMERON, 2003a; LARSEN-FREEMAN, 2003). Van Geert (1994) argumenta que a zona de desenvolvimento proximal (ZDP) de Vygotsky ${ }^{10}$ pode ser construída na forma de um modelo de sistemas dinâmicos, os quais produzem uma variedade de padrões de crescimento não-lineares. Mais importante, com este princípio central de que o uso e a aprendizagem da língua são processos sociais, a teoria sociocultural (e.g. LANTOLF, 2006a) compartilha com a teoria da complexidade a ideia de que a aprendizagem e a língua podem emergir das interações de indivíduos.

\footnotetext{
10 A ZDP é definida como a diferença entre o que uma pessoa pode fazer sozinha e o que uma pessoa pode fazer quando está trabalhando com outros ou com um outro que possui maior conhecimento.
} 


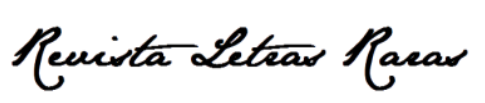

ISSN: 2317-2347 - v. 9, n. 4 (2020)

Todo o conteúdo da RLR está licenciado sob Creative Commons Atribuição 4.0 Internacional

A abordagem realista social de Sealey e Carter (2004) também enxerga a ação humana em relação aos fenômenos sociais, e, da mesma forma, pode fornecer uma abordagem da complexidade com muitos conceitos em torno da interconexão da estrutura e da ação.

As abordagens ecológicas na linguística aplicada possuem um sistema complexo específico, um sistema ecológico, para usar como uma metáfora-base para considerar como usuários e aprendizes da língua interagem com seu meio ambiente ou contexto. As abordagens ecológicas (ver, por exemplo, as contribuições em KRAMSCH, 2002; LEATHER; VAN DAM 2003; VAN LIER, 2004) que focam em um entendimento das relações, podem, portanto, contribuir para uma estrutura da complexidade de várias formas. Abordagens ecológicas forçam uma consciência da interconectividade de indivíduos, pares de indivíduos, comunidades, etc., ou, como Clarke (2007) se refere, dos "sistemas dentro de sistemas dentro de sistemas".

À medida que o livro avança, baseamo-nos nessas abordagens e teorias para criar uma abordagem da complexidade para a linguística aplicada.

\section{Este livro}

Iniciamos o Capítulo 2 explorando os conceitos incluídos nos sistemas complexos. Conceitos são introduzidos ao longo do capítulo, iniciando com a ideia de que um "sistema" é um conjunto de componentes e que as relações dentre os componentes concedem uma identidade como um todo. Contrastamos sistemas simples, em que as relações dentre os componentes não mudam, com sistemas complexos, em que as relações mudam frequentemente de forma nãolinear. As propriedades centrais dos sistemas complexos são introduzidas, exemplificadas e discutidas em relação aos sistemas da linguística aplicada: dinamismo, complexidade, abertura, não-linearidade, auto-organização, adaptação e surgimento. 0 capítulo se direciona, então, para uma discussão dos avanços recentes em compreender a natureza da mudança em sistemas complexos, abordados pelo poder computacional elevado e pelas novas técnicas modeladoras de matemática. Esses avanços significam que sistemas complexos não precisam mais ser idealizados em sistemas mais simples, mas podem ser compreendidos em seus próprios direitos.

No Capítulo 3, exploramos as consequências de dois tipos de mudanças contrastantes que podem ocorrer em um sistema complexo: a mudança estável e a mudança repentina. 0 


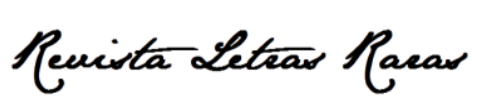

ISSN: 2317-2347 - v. 9, n. 4 (2020)

Todo o conteúdo da RLR está licenciado sob Creative Commons Atribuição 4.0 Internacional

leitor é introduzido às imagens e aos construtos topológicos que são utilizados para descrever as dinâmicas dos sistemas, em que a mudança de sistema é vista como um movimento de uma trajetória através de um "espaço de estado" ou "espaço de fase". Explicamos como a nãolinearidade pode levar a mudanças repentinas e dramáticas, denominadas uma "troca de fase", e como isto é descrito em termos de "atratores". Em um resumo do contexto dos sistemas complexos, é definido um procedimento para explorar os sistemas da linguística aplicada em termos de complexidade. Seguimos com a exploração da relação entre teoria e mundo. Explicamos, a partir de uma perspectiva da teoria da complexidade, o que é visto como necessário para uma investigação empírica. Examinamos a natureza das hipóteses e das teorias, discutindo o que conta como dados, como eles são coletados, o papel do contexto, o que conta como evidência e a natureza das descrições e explicações, particularmente a causalidade. A questão da ação e da intenção humana é discutida e conectada à responsabilidade ética.

Ao estabelecer a base de trabalho e prometer não só desafios, mas também entusiasmo, propomos mostrar nos quatro capítulos seguintes como a teoria dos sistemas complexos pode levar a uma nova consciência na linguística aplicada. Neste capítulo, introduzimos alguns desses sistemas nas nossas sentenças de "e se".

No Capítulo 4, sobre a língua e sua evolução, pontuamos que distinções como competência versus performance que se apoiam em certas teorias linguísticas levantam uma hipótese conveniente, mas problemática, de que a estrutura da língua é independente do uso desta. Entretanto, essa visão de longa data está sendo desafiada por linguistas probabilísticos, cognitivistas e funcionalistas, e por psicólogos desenvolvimentistas, emergentistas, e conexionistas, os quais mantêm a ideia de que representações linguísticas são o produto das experiências dos falantes de uma língua. Essas abordagens baseadas no uso, em relação à língua e ao desenvolvimento desta, enxergam a gramática, a fonologia e o léxico igualmente como sistemas dinâmicos que emergem dos padrões frequentemente ocorridos no uso da língua, mais do que sistemas sincrônicos, fechados, autônomos e fixos. Isto ocorre devido à teoria da complexidade conectar processamentos em tempo real e em toda sua variabilidade para se modificar ao longo do tempo. $O$ valor desta perspectiva é de que a língua não é mais recebida como uma "coisa" mecânica, atemporal, objetificada e idealizada. 0 valor para os linguistas aplicados é de que eles têm acesso a uma conceituação da língua que é muito mais apropriada para lidar com questões desenvolvimentistas, para conectar o uso e a aprendizagem da língua. 


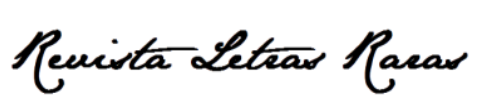

ISSN: 2317-2347 - v. 9, n. 4 (2020)

Todo o conteúdo da RLR está licenciado sob Creative Commons Atribuição 4.0 Internacional

No capítulo 5, discutimos sobre a aquisição de primeira e de segunda língua (ASL) a partir da perspectiva da teoria da complexidade. Qualquer um que tenha estudado aquisição de língua sabe que é algo sistemático e variável. Muito do esforço na ASL se direcionou para questões como "O que significa sistemático?" e "Como a interlíngua de um aprendiz pode ser denominada 'sistemática' quando, na maioria dos dados dos pesquisadores, parece ter tanta variabilidade?" Essa questão é agravada pelo fato de que muito da variabilidade aparenta ser aleatório - às vezes uma forma alvo é fornecida em um texto, às vezes não - levando a caracterizações da performance do aprendiz como não-sistemática, até mesmo "volátil" (LONG, 2003). Diante de tanta volatilidade, é sensato perguntar se a língua do aprendiz é, de fato, sistemática. Enquanto seria difícil de sustentar a noção de uma interlíngua representando estágios lineares e discretos entre dois pontos de competência a partir de uma teoria da complexidade, como veremos no Capítulo 5 , a instabilidade e a variabilidade da performance não precisam ser vistas como uma ameaça para a noção de sistematicidade na (inter)língua. Desta forma, se virmos as interlínguas como sistemas dinâmicos complexos, então a questão de se uma interlíngua é sistemática ou variável não mais surgirá, e poderemos nos concentrar em como encontrar os padrões sistemáticos na variabilidade.

No Capítulo 6, utilizamos os construtos de sistemas complexos para descrever 0 discurso, e começamos pela reinterpretação da conversa cara-a-cara como uma trajetória de um sistema acoplado. Essa estrutura é aplicada para mostrar como vários fenômenos do discurso, desde os pares adjacentes até os gêneros e as expressões idiomáticas podem ser descritas em termos de complexidade. Encontramos uma forma intrigante de enxergar o uso da língua como uma propriedade do discurso e não dos indivíduos, com os indivíduos apenas tendo um potencial latente para o uso da língua até eles perceberem isto em um entorno discursivo. Teorias linguísticas tradicionais como um sistema não possuem espaço para o figurativo, e ainda assim é uma característica difundida e inerente do uso da língua, e tal qual, precisa ser considerada. A rejeição prematura de aspectos da língua em uso, como foi imposto pelas abordagens Saussurianas e Chomskianas para a teoria linguística, aparentam ser particularmente arriscadas para a linguística aplicada - precisamos de teorias sobre o uso real da língua para informar as pesquisas sobre o uso real da língua.

No Capítulo 7, veremos como a teoria da complexidade nos dá uma média para considerar os fenômenos emergentes de formas coletivas que refletem a interação entre pessoas, mentes e língua em salas de aula. Enquanto resistimos à ideia de um "método da 


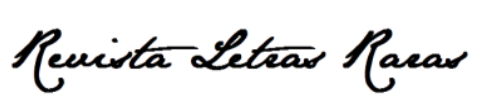

ISSN: 2317-2347 - v. 9, n. 4 (2020)

Todo o conteúdo da RLR está licenciado sob Creative Commons Atribuição 4.0 Internacional

complexidade" como inapropriado, oferecemos quatro fundamentos de uma abordagem da complexidade para a sala de aula de língua e ilustramo-los através de dados reinterpretados de situações de segunda língua e língua estrangeira. Cada turma de alunos e professores apresenta diferentes padrões de interação e comportamento. Observar como o uso da língua na relação professor-aluno se coadapta em padrões estáveis pode ajudar a diagnosticar problemas e a elaborar intervenções apropriadas a fim de melhorar o gerenciamento da dinâmica da aprendizagem.

Obviamente é importante, também, perguntar sobre as "diretrizes empíricas" advindas de uma abordagem da teoria da complexidade (Candlin, comentário em KRAMSCH, 2002, p. 91), a qual torna-se distinta de outras abordagens. Portanto, concluímos este livro com uma discussão no Capítulo 8 sobre como seria um plano de investigação para a linguística aplicada a partir de uma perspectiva de sistemas complexos. Neste último capítulo, revisamos as "diretrizes empíricas" de uma abordagem da complexidade, examinando adaptações de métodos existentes ao lado de novos métodos, como a modelagem matemática, experimentos formativos, e estudos de concepção.

\section{Conclusão}

O surgimento do interesse em nossa área no caos e nas metáforas da complexidade nos últimos anos sugere que isto tenha um apelo particular e oportuno. O foco na conectividade, mudança e dinâmica se encaixa com o que as pessoas vêm acontecer com suas vidas com a necessidade do rumo a globalização, o aumento com o poder da computação, a velocidade e a pressão de uma vida pós-moderna, a imprevisibilidade aparente dos eventos mundiais, e o reconhecimento de uma responsabilidade compartilhada para assegurar-se da sobrevivência no planeta Terra. Entretanto, acreditamos que a teoria da complexidade, como uma metáfora ou como uma grande abordagem, oferece muito mais do que meramente um encaixe com o espírito da época e pode realizar uma contribuição valiosa para o desenvolvimento da linguística aplicada para sua ontologia e para sua epistemologia. Alguns, como o cientista da complexidade Kauffman (1995, p. 303-304) iria mais longe:

Se as teorias de emergência que temos discutido aqui têm mérito, talvez estejamos em casa no universo de formas que não sabíamos desde que sabíamos muito pouco para duvidar. Eu não sei se as teorias de emergência 


\section{Reuista Leteas Paras}

ISSN: 2317-2347 - v. 9, n. 4 (2020)

Todo o conteúdo da RLR está licenciado sob Creative Commons Atribuição 4.0 Internacional

... se provarão corretas. Mas essas histórias não são evidentemente tolas. Elas são fragmentos e peças de uma nova arena da ciência, uma ciência que crescerá nas próximas décadas em direção à algumas novas visões da emergência e ordem neste universo longe-de-ser-equilibrado que é nossa casa.

\section{Referência}

LARSEN-FREEMAN, Diane; CAMERON, Lynne. Complex Systems and Applied Linguistics. Oxford: Oxford University Press. 